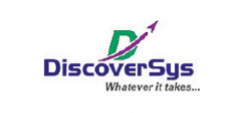

Published by DiscoverSys

\section{Good parental feeding style reduces the risk of stunting among under-five children in Yogyakarta, Indonesia}

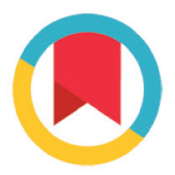

CrossMark

\author{
Erni Gustina, ${ }^{1 *}$ Liena Sofiana, ${ }^{1}$ Suci Musvita Ayu,${ }^{1}$ Yuniar Wardani, ${ }^{1}$ Ditra Irna Lasari, ${ }^{1}$
}

\section{ABSTRACT}

Background and purpose: In Indonesia, many studies on the causes of stunting in children have been conducted. However, still few have explored the parental feeding style in relation to stunting. The purpose of this study was to analyze the relationship between parental feeding style and stunting among under-five children in Kulon Progo District, Yogyakarta.

Methods: This study used a cross sectional design. This study involved 729 respondents who were the entire population of under-five children in Kulon Progo. Mothers were interviewed about the socio-demographic, economic and parental feeding style that mothers gave to their children using a structured questionnaire. Data were analyzed descriptively to identify the frequency distribution of each variable, hypothesis testing with chi square test and multivariable analysis with logistic regression at a significance level of $5 \%$ were performed.
Results: Of the 729 under-five children analyzed, $37.6 \%$ were found to be stunting. The proportion of poor parental feeding style was almost $50 \%$. The finding of this study showed that mother's occupation (AOR=2.13; $95 \% \mathrm{Cl}$ : 1.26-3.59), family income ( $\mathrm{AOR}=3.56 ; 95 \% \mathrm{Cl}$ : 2.34-5.42) and parental feeding style $(A 0 R=2.77 ; 95 \% C l: 1.97-3.91)$ have a significant relationship with stunting.

Conclusion: The prevalence of stunting is quite high in the study area. Parents with poor parental feeding style are predicted to increase the risk of stunting among under-five children. Familybased interventions that involve parenting styles in child feeding practices should be considered in reducing stunting among children.
${ }^{1}$ Department of Public Health, Faculty of Public Health, Universitas Ahmad Dahlan, Yogyakarta, Indonesia

*Correspondence to: Erni Gustina; Department of Public Health, Faculty of Public Health, Universitas Ahmad Dahlan, Yogyakarta, Indonesia;

erni.gustina@ikm.uad.ac.id

Keywords: family income, mother's occupation, parenting feeding style, stunting, under-five children.

Cite this Article: Gustina, E., Sofiana, L., Ayu, S.M., Wardani, Y., Lasari, D.I. 2020. Good parental feeding style reduces the risk of stunting among under-five children in Yogyakarta, Indonesia. Public Health and Preventive Medicine Archive 8(2): 120-125. D0I: 10.15562/phpma. v8i2.306

\section{INTRODUCTION}

Stunting is a chronic malnutrition problem caused by lack of nutritional intake for a long time, causing growth problems in children where the child's height is shorter than the standard age. Stunting is considered a public health problem when the prevalence of stunting is above $20 \%$. $^{1}$ The prevalence of stunting varies between countries. Prevalence of stunting in Tanzania was $35.5 \%^{2}$, in Nepal $26.3 \%^{3}$, in Northwest Ethiopia $49.9 \%{ }^{4}$, in Rwanda $38 \%{ }^{5}$ and in Indonesia was $30.8 \%$ in $2018 .^{6}$ Meanwhile, the WHO target by 2025 is to reduce the prevalence of stunting in children under five by $40 \%$.

Stunting is associated with developmental domains $^{8}$ namely lower psycho-motoric development experienced by the children ${ }^{9,10}$, poor cognitive development in children ${ }^{11,12} 55 \%$ of children $<5$ y were anemic and $40 \%$ stunted in 2010. Currently, no data exists on the nutritional status of Cambodian school-aged children, or on how malnutrition potentially affects their cognitive development. Objective: To assess the anthropometric and micronutrient status (iron, vitamin $A$, zinc, iodine but did not affect social maturity in children. ${ }^{13}$ Stunting is associated with pneumonia in which stunting children have a higher risk of experiencing longer recovery. ${ }^{14}$

Stunting is caused by multi-factors. Good parental education is associated with better child growth. Parental education, household wealth index, length of breastfeeding, sex of child, low birth weight, lack of access to health services including sub-optimal antenatal care, delivery not in health care facilities (home delivery), lack of sanitation and low maternal knowledge regarding child nutrition are predictors for stunting in children. ${ }^{3,15-18}$ Stunting is also associated with the practice of parent feeding, where parent-to-child feeding determines the child's eating behavior and weight gain. ${ }^{19}$

Several studies on child feeding practices have been carried out, but the focus of previous researchers was on child feeding practices related to children's nutritional status ${ }^{20-22}$, obesity ${ }^{23}$, the pressure to eat with stunting ${ }^{24}$, and parenting with 
stunting. ${ }^{25}$ The focus of our study is different from previous studies, we explore relationship between parental feeding styles and stunting in children. We included independent variables such as family income, mother's employment status and parental feeding styles. The finding from this study will help policymakers developing stunting prevention intervention by accommodating parenting styles in their children's feeding practices. Therefore, the purpose of this research was to identify the relationship between parental feeding style and stunting in under-five years in Kulon Progo District, Yogyakarta, Indonesia.

\section{METHODS}

This research was conducted using a cross-sectional design from May to July 2019 to determine association between parental feeding styles with stunting in under-five children. The research population is under-five children in five subdistricts in Kulon Progo District which consists of 9 villages. Five sub-districts in 2017 rank 43 out of 100 districts which need further intervention related to stunting cases. A total population sampling technique $(\mathrm{n}=729)$ was applied. The mother was interviewed about socio-demographic, economic and parental feeding style that the mother gives to her child with a structured questionnaire that has been tested previously.

Data collected by enumerators are primary data obtained through a questionnaire modified from the Child Feeding Questionnaire (CFQ $)^{26}$ and Parental Feeding Style Questionnaire (PFSQ). ${ }^{27}$ We use the four scales in Parental Feeding Style Questionnaire: emotional feeding where the behavior or way parents provide food to children in response to feelings (e.g. I give my son something to eat so he will feel better when he worries); encouragement to eat is the way parents give in encouraging children to eat (e.g. I serve food in an interesting way for my child to eat); control over eating is the mother determines what foods to eat and when the child should eat; (4) instrumental feeding the way parents reward children by providing food if they exhibit the behavior the parents command (e.g. I gift my child with something to eat when he is wellbehaved). We categorize the parental feeding style into two category: good parental feeding style if the total score is $\geq 45$; parental feeding style is not good if the total score is $<45$.

Meanwhile, secondary data was obtained from data on the number of children under five and the nutritional status of under-five children in the Kulon Progo District Health Office in 2018. The modification of questionnaire was carried out before the validity test with $r>0.3$ and Cronbach alpha value 0.68 . Data were analyzed descriptively to identify the frequency distribution of each research variable. Hypotheses testing using the Chi Square Test and multivariable analysis with multiple logistic regression were performed to produce the adjusted odds ratio (AOR). Hypotheses were tested at a 5\% significance level and a 95\% level of confidence.

This research has received an ethical clearance from the Universitas Ahmad Dahlan Ethics Committee with number 011903012 in 2019. Informed consents were given to respondents to ensure that respondents voluntarily participated in this research.

\section{RESULTS}

Of the 729 under-five children involved in the study, more than half (53.77\%) were male. Children's age also varies in each category. The majority $(70.29 \%)$ of the mothers in this study were in the age range of 20-35 years. Meanwhile, two third of parents' education was at a high school level $(67.35 \%$ for mother's and $61.04 \%$ for father's education), and most of the mothers were not working (82.17\%). Family income mostly fell in the low category (69.14\%) (Table 1). In this study, the prevalence of stunting was $37.6 \%$. The proportion of poor parental feeding style was almost as high as $50 \%$ (Table 2).

Based on parental feeding style, proportion of stunting in children with poor parental feeding style (51\%) was twice higher than those with good parental feeding style (25.26\%). There is not much difference on the proportion based on sex, while based on age group, the proportion of stunting among older age groups was higher than younger age groups.

The bivariate analysis with chi square test shows that stunting is related to mother's occupation, family income, parent's education, mother's age and parental feeding style (Table 4). The multivariate analysis was used to determine predictors of stunting. The results of the analysis presented in Table 5 show that stunting among children under five is higher in mothers who were not working and from high risk age group ( $<20$ years and $>35$ years), also if the fathers have low education and the family from low income group. Parental feeding style $(\mathrm{AOR}=2.77$; 95\%CI: 1.97-3.91) has a relationship with stunting, where children whose parents have poor parental feeding style are 2.89 times more likely to experience stunting compared to parents who have good parental feeding style. 
Table 1. Socio-demographic characteristics of children and parents $(n=729)$

\begin{tabular}{|c|c|c|}
\hline Characteristics & $\mathbf{n}$ & $\%$ \\
\hline \multicolumn{3}{|l|}{ Sex of child } \\
\hline Male & 392 & 53.77 \\
\hline Female & 337 & 46.23 \\
\hline \multicolumn{3}{|l|}{ Age of child (months) } \\
\hline $0-12$ & 107 & 14.68 \\
\hline $13-24$ & 150 & 20.58 \\
\hline $25-36$ & 180 & 24.69 \\
\hline $37-48$ & 175 & 24.01 \\
\hline $49-59$ & 117 & 16.05 \\
\hline \multicolumn{3}{|l|}{ Mother's age (years) } \\
\hline$<20$ & 2 & 0.27 \\
\hline $20-35$ & 517 & 70.92 \\
\hline$>35$ & 210 & 28.81 \\
\hline \multicolumn{3}{|l|}{ Mother's education } \\
\hline Elementary school & 41 & 5.62 \\
\hline Middle school & 154 & 21.12 \\
\hline High school & 491 & 67.35 \\
\hline Higher education & 43 & 5.90 \\
\hline \multicolumn{3}{|l|}{ Father's education } \\
\hline Elementary school & 81 & 11.11 \\
\hline Middle school & 165 & 22.63 \\
\hline High school & 445 & 61.04 \\
\hline Higher education & 38 & 5.21 \\
\hline \multicolumn{3}{|l|}{ Mother's occupation } \\
\hline Not working & 599 & 82.17 \\
\hline Working & 130 & 17.83 \\
\hline \multicolumn{3}{|l|}{ Family income } \\
\hline Low & 504 & 69.14 \\
\hline High & 225 & 30.86 \\
\hline Total & 729 & 100.0 \\
\hline
\end{tabular}

Table 2. Frequency distribution of stunting and parental feeding style

\begin{tabular}{lll}
\hline \multicolumn{1}{c}{ Characteristics } & $\mathbf{n}$ & \% \\
\hline Stunting & & \\
$\quad$ Yes & 274 & 37.59 \\
$\quad$ No & 455 & 62.41 \\
Parental feeding style & & \\
$\quad$ Poor & 349 & 47.87 \\
$\quad$ Good & 380 & 52.13 \\
\hline Total & $\mathbf{7 2 9}$ & $\mathbf{1 0 0 . 0}$ \\
\hline
\end{tabular}

\section{DISCUSSION}

The prevalence of stunting in this population is $37.6 \%$. The prevalence of stunting in this study is above the national level of $30.8 \%{ }^{6}$ We found maternal occupation, mothers' age, family income, father's education and parental feeding style were associated with stunting.

Socioeconomic status is usually reflected from education, income and work position at the individual level. Socioeconomic status has an impact on children's nutrition. ${ }^{28}$ In this study, the majority of maternal education is high school, most of them were not working and family income is in the low income category. Mothers with low levels of education increased the risk of stunting. Children of mothers with no education or with only elementary education had a $77 \%$ increase in risk of stunting compared with children of mothers with tertiary education. ${ }^{29}$ Mothers who are not working may result in low-income households. The possible impact is lack of nutrition for children to achieve optimal growth. Unmet need for physical development in children can result in stunted growth. ${ }^{4}$

Mothers aged between 20-35 years, consider as low risk age group for having a baby, were associated with lower odds of stunting which may related to education, family income and better preparedness on nurturing a child. Maternal age is an important predictor of stunting. Children of adult mothers were less likely to be stunted than children of teenage mothers and older mothers. ${ }^{30}$ Children of teenage mothers were 8 times more likely to be stunted than adult mothers. Adolescent mothers are less able to ensure adequate food intake for their children due to household food insecurity, inappropriate parenting practices compared to adult mothers which can affect the growth and development of children resulting in malnutrition. ${ }^{31}$

Meanwhile, father's education and family income were also associated with stunting, where father's education is likely correlated with better occupation which lead to better income. Children who have fathers with postsecondary education are less likely to be stunted. ${ }^{32}$ Parents who completed higher formal education will reduce the risk of their children becoming stunted. ${ }^{33}$ The results of the study indicate that high parental education has a correlation with household wealth. ${ }^{34}$ Children with poor families are more likely to be stunted than children with rich families. ${ }^{35}$

Stunting is more common in children who live in low-income households, or where mothers have low education. ${ }^{36}$ Children living in the poorest households are almost five times more likely to be stunted than children from the richest households. ${ }^{37}$ The socioeconomic status of parents greatly influences nutritional status, where household asset-based income shows an effect on nutritional status. Low socioeconomic status indicates poor nutritional status, and high socioeconomic status 
Table 3. Frequency distribution of stunting based on parental feeding style, sex and age of child

\begin{tabular}{|c|c|c|c|c|}
\hline \multirow{3}{*}{ Variables } & \multicolumn{4}{|c|}{ Stunting } \\
\hline & \multicolumn{2}{|c|}{ Yes } & \multicolumn{2}{|c|}{ No } \\
\hline & $\mathbf{n}$ & $\%$ & $\mathbf{n}$ & $\%$ \\
\hline \multicolumn{5}{|c|}{ Parental feeding styles } \\
\hline Poor & 178 & 51.00 & 171 & 49.00 \\
\hline Good & 96 & 25.26 & 284 & 74.74 \\
\hline \multicolumn{5}{|l|}{ Sex of child } \\
\hline Male & 154 & 39.29 & 238 & 60.71 \\
\hline Female & 120 & 35.61 & 217 & 64.39 \\
\hline \multicolumn{5}{|c|}{ Age of child (months) } \\
\hline $0-12$ & 22 & 20.56 & 85 & 79.44 \\
\hline $13-24$ & 41 & 27.33 & 109 & 72.67 \\
\hline $25-36$ & 89 & 49.44 & 91 & 50.56 \\
\hline $37-48$ & 75 & 42.86 & 100 & 57.14 \\
\hline $49-59$ & 47 & 40.17 & 70 & 59.41 \\
\hline Total & 274 & 37.59 & 455 & 62.41 \\
\hline
\end{tabular}

Table 4. Crude OR of stunting based on several factors

\begin{tabular}{|c|c|c|c|c|c|}
\hline \multirow{3}{*}{ Variables } & \multicolumn{2}{|c|}{ Stunting } & \multirow{3}{*}{ Total } & \multirow{3}{*}{$\mathbf{p}$} & \multirow{3}{*}{$\begin{array}{c}\text { OR } \\
95 \% \mathrm{Cl}\end{array}$} \\
\hline & Yes & No & & & \\
\hline & $\%$ & $\%$ & & & \\
\hline \multicolumn{6}{|l|}{ Mother's occupation } \\
\hline Not working & 41.90 & 58.10 & 130 & $<0.001$ & $2.37(1.62-3.47)$ \\
\hline Working & 17.69 & 82.31 & 599 & & \\
\hline \multicolumn{6}{|l|}{ Family income } \\
\hline Low & 46.23 & 53.77 & 504 & $<0.001$ & $2.54(1.89-3.39)$ \\
\hline High & 18.22 & 81.78 & 225 & & \\
\hline \multicolumn{6}{|l|}{ Mother's education } \\
\hline Low & 30.26 & 69.75 & 195 & 0.014 & $1.33(1.05-1.69)$ \\
\hline High & 40.26 & 59.74 & 534 & & \\
\hline \multicolumn{6}{|l|}{ Father's education } \\
\hline Low & 21.54 & 78.46 & 246 & $<0.001$ & $2.12(1.64-2.75)$ \\
\hline High & 45.76 & 54.24 & 483 & & \\
\hline \multicolumn{6}{|l|}{ Mother's age (Years) } \\
\hline $20-35$ & 31.91 & 60.89 & 517 & $<0.001$ & $0.62(0.52-0.74)$ \\
\hline$<20$ or $>35$ & 51.42 & 48.58 & 212 & & \\
\hline \multicolumn{6}{|l|}{ Parental feeding } \\
\hline Poor & 25.26 & 74.74 & 380 & & \\
\hline Good & & & & & \\
\hline Total & 37.59 & 62.41 & 729 & & \\
\hline
\end{tabular}

indicates good nutritional status. ${ }^{25}$ Families with high household wealth tend to have better food security in their families so that their children get better food quantitatively and qualitatively. ${ }^{38}$

This study shows that stunting in under-five children occurs in parents with poor parental feeding style. The practice of feeding children is predicted to be the cause of stunting. ${ }^{39-42}$ Parents with low knowledge about eating restriction and feeding pressure are thought to play a role as predictors of stunting. Eating pressure includes how parents determine how much food is sufficient for their children. ${ }^{24}$ Lack of parental awareness contributes to poor behavior in child feeding practices. ${ }^{43}$ Low parental knowledge about nutrition was found to be associated with low cognitive performance of children as well. ${ }^{44}$

Parents who involve good parenting styles in feeding practices have the opportunity to have children with good eating behavior. Parents who exercise restrictions and pressure on eating in children are associated with the authoritarian parenting style adopted by the parents. Parents who are able to apply authoritative parenting to feeding practices are able to increase their children's appetite. ${ }^{45}$ Mothers with authoritative feeding practices are able to improve the health of their children compared to authoritarian and permissive parenting styles. ${ }^{46,47}$

The parenting style in providing food ${ }^{46}$ and the quality of care provided by parents ${ }^{48}$ should be of more concern to achieve health in children. Community-based counseling and support for infant and child feeding must be provided to parents so that they are able to provide appropriate feeding practices for children. Interventions to reduce stunting need to be conducted by strengthening messages about child feeding by involving parenting styles in child feeding practices so as to increase positive responsive eating behavior. ${ }^{47,49}$

\section{CONCLUSION}

The prevalence of stunting was quite high in the study area. Poor parental feeding style in this study was practiced by almost $50 \%$ of parents. Parents with poor parental feeding style showed an increase risk of stunting in under-five children. Therefore, there is a need to introduce family-based interventions in the practice of feeding children by involving parenting styles in reducing stunting problems.

\section{ACKNOWLEDGMENT}

Researchers would like to thank the Institute of Research and Community Service Universitas Ahmad Dahlan and people of Kulon Progo District who have participated in this research.

\section{AUTHOR CONTRIBUTION}

EG designed the study, analyzed the data, wrote the manuscript and edited the manuscript. LS, SMA, YW were involved in research design, supported the data analysis and edited the manuscript, DIL collected the data. 
Table 5. AOR of stunting among under-five children based on several factors

\begin{tabular}{|c|c|c|}
\hline Variables & $\begin{array}{c}\text { Unadjusted OR } \\
(95 \% \mathrm{Cl})\end{array}$ & $\begin{array}{c}\text { Adjusted OR } \\
(95 \% \mathrm{Cl})\end{array}$ \\
\hline \multicolumn{3}{|c|}{ Mother's occupation } \\
\hline Not working & 1 & 1 \\
\hline Working & $2.37(1.62-3.47)^{* * *}$ & $2.13(1.26-3.59)^{\star *}$ \\
\hline \multicolumn{3}{|l|}{ Family income } \\
\hline Low & 1 & 1 \\
\hline High & $2.54(1.89-3.39)^{\star * *}$ & $3.56(2.34-5.42)^{* * *}$ \\
\hline \multicolumn{3}{|l|}{ Mother's education } \\
\hline Low & 1 & 1 \\
\hline High & $1.33(1.05-1.69)^{\star \star}$ & $1.14(0.74-1.75)$ \\
\hline \multicolumn{3}{|l|}{ Father's education } \\
\hline Low & 1 & 1 \\
\hline High & $2.12(1.64-2.74)^{* * *}$ & $3.43(2.26-5.22)^{* * *}$ \\
\hline \multicolumn{3}{|l|}{ Mother's age (Years) } \\
\hline $20-35$ & 1 & 1 \\
\hline$<20$ or $>35$ & $0.62(0.52-0.74)$ & $0.56(0.37-0.81)$ \\
\hline \multicolumn{3}{|c|}{ Parental feeding style } \\
\hline Poor & 1 & 1 \\
\hline Good & $2.02(1.65-2.47)^{\star * *}$ & $2.77(1.97-3.91)^{* * *}$ \\
\hline
\end{tabular}

${ }^{*} \mathrm{p}<0.05 ;{ }^{* *} \mathrm{p}<0.01 ;{ }^{* *} \mathrm{p}<0.001 ;$ Psedu $\mathrm{R}^{2}=0.18 ; \mathrm{CI}=$ Confidence Interval; Level of Significance at $\mathrm{p}<0.05$
8. Miller AC, Murray MB, Thomson DR, Arbour MC. How consistent are associations between stunting and child development? Evidence from a meta-analysis of associations between stunting and multidimensional child development in fifteen low- and middle-income countries. Public Health Nutr. 2016;19(8):1339-1347.

9. Hanum NL, Khomsan A. Pola asuh makan, perkembangan bahasa, dan kognitif anak balita stunted dan normal di Kelurahan Sumur Batu, Bantar Gebang Bekasi [Feeding practices, language and cognitive development among stunted and normal under-five children in Sumur Batu Village, Bantar Gebang Bekasi]. J Gizi dan Pangan. 2012;7(2):81.

10. Rothman M, Faber M, Covic N, Matsungo TM, Cockeran M, Kvalsvig JD, et al. Infant development at the age of 6 months in relation to feeding practices, iron status, and growth in a peri-urban community of South Africa. Nutrients. 2018;10(1):1-13.

11. Perignon M, Fiorentino M, Kuong K, Burja K, Parker M, Sisokhom S, et al. Stunting, poor iron status and parasite infection are significant risk factors for lower cognitive performance in Cambodian school-aged children. PLoS One. 2014;9(11).

12. Woldehanna T, Behrman JR, Araya MW. The effect of early childhood stunting on children's cognitive achievements: Evidence from young lives Ethiopia. Ethiop J Heal Dev. 2017;31(2):75-84.

13. Casale D, Desmond C, Richter L. The association between stunting and psychosocial development among preschool children: A study using the South African Birth to Twenty cohort data. Child Care Health Dev. 2014;40(6):900-10.

14. Moschovis PP, Addo-Yobo EOD, Banajeh S, Chisaka N, Christiani DC, Hayden D, et al. Stunting is associated with poor outcomes in childhood pneumonia. Trop Med Int Heal. 2015;20(10):1320-1328.

15. Akombi BJ, Agho KE, Hall JJ, Wali N, Renzaho AMN, Merom D. Stunting, wasting and underweight in SubSaharan Africa: A systematic review. Int J Environ Res Public Health. 2017;14(8):1-18.

16. Mgongo M, Chotta NAS, Hashim TH, Uriyo JG, Damian DJ, Stray-Pedersen B, et al. Underweight, stunting and wasting among children in Kilimanjaro region, Tanzania; a population-based cross-sectional study. Int J Environ Res Public Health. 2017;14(5):1-12.

2. Chirande L, Charwe D, Mbwana H, Victor R, Kimboka $\mathrm{S}$, Issaka AI, et al. Determinants of stunting and severe stunting among under-fives in Tanzania: Evidence from the 2010 cross-sectional household survey. BMC Pediatr. 2015;15(1):1-13.

3. Tiwari R, Ausman LM, Agho KE. Determinants of stunting and severe stunting among under-fives: Evidence from the 2011 Nepal Demographic and Health Survey. BMC Pediatr. 2014;14(239):1-15.

4. Geberselassie SB, Abebe SM, Melsew YA, Mutuku SM, Wassie MM. Prevalence of stunting and its associated factors among children 6-59 months of age in LiboKemekem district, Northwest Ethiopia; A community based cross sectional study. PLoS One. 2018;13(5):1-11.

5. Nshimyiryo A, Hedt-Gauthier B, Mutaganzwa C, Kirk CM, Beck K, Ndayisaba A, et al. Risk factors for stunting among children under five years: A cross-sectional populationbased study in Rwanda using the 2015 Demographic and Health Survey. BMC Public Health. 2019;19(1):1-10.

6. The Ministry of Health of The Republic of Indonesia. Hasil Utama Laporan Riskesdas 2018 [The main results of The 2018 Basic Health Research Report]. The Ministry of Health of The Republic of Indonesia. Jakarta; 2018.

7. World Health Organization. WHA Global Nutrition Targets 2025: Stunting Policy Brief. Geneva: World Health Organization. 2014.
17. Nkurunziza S, Meessen B, Van geertruyden JP, Korachais C. Determinants of stunting and severe stunting among Burundian children aged 6-23 months: Evidence from a national cross-sectional household survey, 2014. BMC Pediatr. 2017;17(1):1-14.

18. Vaivada T, Akseer N, Akseer S, Somaskandan A, Stefopulos M, Bhutta ZA. Stunting in childhood: An overview of global burden, trends, determinants, and drivers of decline. Am J Clin Nutr. 2020;112(Suppl):777S-791S.

19. Jansen PW, Tharner A, Ende J Van Der, Wake M, Raat H, Hofman A, et al. Feeding practices and child weight: is the association bidirectional in preschool children? Am J Clin Nutr. 2014;100:1329-1336.

20. Adnan N, Muniandy ND. The relationship between mothers' educational level and feeding practices among children in selected kindergartens in Selangor, Malaysia: A cross-sectional study. Asian Journal of Clinical Nutrition. 2012;4(2):39-52.

21. Shloim N, Edelson LR, Martin N, Hetherington MM. Parenting styles, feeding styles, feeding practices, and weight status in 4-12 year-old children: A systematic review of the literature. Front Psychol. 2015;6:1-20. pemberian makan, perawatan kesehatan, dan kebersihan anak dengan kejadian stunting pada anak usia 1-2 tahun
22. Niga DM, Purnomo W. Hubungan antara praktik 
di wilayah kerja Puskesmas Oebobo Kota Kupang [The association between feeding practices helath care and children's hygiene with stunting among children aged 1-2 years in the area of Oebobo Public Health Center, Kupang City]. J Wiyata. 2016;3(2):151-155.

23. Tschann JM, Martinez SM, Penilla C, Gregorich SE, Pasch LA, de Groat CL, et al. Parental feeding practices and child weight status in Mexican American families: A longitudinal analysis. Int J Behav Nutr Phys Act. 2015;12(1):1-10.

24. Dranesia A, Wanda D, Hayati H. Pressure to eat is the most determinant factor of stunting in children under 5 years of age in Kerinci region, Indonesia. Enferm Clin. 2019;(xx):16.

25. Aramico B, Sudargo T, Susilo J. Hubungan sosial ekonomi, pola asuh, pola makan dengan stunting pada siswa sekolah dasar di Kecamatan Lut Tawar, Kabupaten Aceh Tengah [The association between socioeconomic status, caring and eating styles with stunting among elementary school students in Tut Tawar Sub-District, Aceh Tengah District]. J Gizi dan Diet Indones. 2016;1(3):121.

26. Birch LL, Fisher JO, Grimm-Thomas K, Markey CN, Sawyer R, Johnson SL. Confirmatory factor analysis of the Child Feeding Questionnaire: A measure of parental attitudes, beliefs and practices about child feeding and obesity proneness. Appetite. 2001;36(3):201-210.

27. Wardle J, Sanderson S, Guthrie CA, Rapoport L, Plomin R. Parental feeding style and the intergenerational transmission of obesity risk. Obes Res. 2002;10(6):453-462.

28. World Health Organization. Reducing stunting in children. Equity considerations for achieving the Global Nutrition Targets 2025. Geneva: World Health Organization [Internet]; 2018. 40 p. Available from: https://apps.who.int/ iris/bitstream/handle/10665/260202/9789241513647-eng. pdf? sequence $=1$

29. Beal T, Le DT, Trinh TH, Burra DD, Huynh T, Duong TT, et al. Child stunting is associated with child, maternal, and environmental factors in Vietnam. Matern Child Nutr. 2019;15(4).

30. Darteh EKM, Acquah E, Kumi-Kyereme A. Correlates of stunting among children in Ghana. BMC Public Health. 2014;14(1).

31. Wemakor A, Garti H, Azongo T, Garti H, Atosona A. Young maternal age is a risk factor for child undernutrition in Tamale Metropolis, Ghana. BMC Res Notes. 2018;11(1):1-5.

32. Balogun TB, Yakubu AM. Recent illness, feeding practices and father's education as determinants of nutritional status among preschool children in a rural Nigerian community. $J$ Trop Pediatr. 2015;61(2):92-99.

33. Soekatri MYE, Sandjaja S, Syauqy A. Stunting was associated with reported morbidity, parental education and socioeconomic status in 5-12-year-old Indonesian children. Int J Environ Res Public Health. 2020;17(17):1-9.

34. Alderman H, Headey DD. How Important is Parental Education for Child Nutrition?. World Dev. 2017;94:44864 .

35. Haile D, Azage M, Mola T, Rainey R. Exploring spatial variations and factors associated with childhood stunting in Ethiopia: spatial and multilevel analysis. BMC Pediatr. 2016;1-14.
36. Ikeda N, Irie Y, Shibuya K. Determinants of reduced child stunting in Cambodia: analysis of pooled data from three Demographic and Health Surveys. Bull World Health Organ. 2013;91(5):341-9.

37. Garcia S, Sarmiento OL, Forde I, Velasco T. Socioeconomic inequalities in malnutrition among children and adolescents in Colombia: The role of individual-, household- and community-level characteristics. Public Health Nutr. 2013;16(9):1703-1718.

38. Mahmudiono T, Nindya TS, Andrias DR, Megatsari H, Rosenkranz RR. Household food insecurity as a predictor of stunted children and overweight/obese mothers (SCOWT) in Urban Indonesia. Nutrients. 2018;10(5):1-16.

39. Santos Felisbino-Mendes M, Villamor E, VelasquezMelendez G. Association of maternal and child nutritional status in Brazil: A population based cross-sectional study. PLoS One. 2014;9(1):1-8.

40. Aitsi-Selmi A. Households with a stunted child and obese mother: Trends and child feeding practices in a middleincome country, 1992-2008. Matern Child Health J. 2015;19(6):1284-1291.

41. Negash C, Whiting SJ, Henry CJ, Belachew T, Hailemariam TG. Association between maternal and child nutritional status in Hula, rural Southern Ethiopia: A cross sectional study. PLoS One. 2015;10(11):1-8.

42. Silva D e., Valente A, Borges A, Dias C, Almeida F, Cruz JL, et al. Relationship between the mothers' nutritional status with that of a child population from são Tomé principe, Africa. Rev Bras Saude Matern Infant. 2017;17(2):327-335.

43. Ma JQ, Zhou LL, Hu YQ, Liu SS, Sheng XY. Association between feeding practices and weight status in young children. BMC Pediatr. 2015;15(1):1-10.

44. Nasir Mohd MT, Norimah AK, Hazizi AS, Nurliyana AR, Loh SH, Suraya I. Child feeding practices, food habits, anthropometric indicators and cognitive performance among preschoolers in Peninsular Malaysia. Appetite. 2012;58(2):525-530.

45. Hartono R, Ipa A, Sirajuddin, Amir A, Ishak SIZS. Feeding style for children aged 0-59 months of buginese ethnicity. Indian J Forensic Med Toxicol. 2020;14(3):1216-1220.

46. Kiefner-Burmeister A, Hoffmann D, Zbur S, MusherEizenman D. Implementation of parental feeding practices: Does parenting style matter?. Public Health Nutr. 2016;19(13):2410-2414.

47. Fisher JO, Serrano EL, Foster GD, Hart CN, Davey A, Bruton YP, et al. Efficacy of a food parenting intervention for mothers with low income to reduce preschooler's solid fat and added sugar intakes: A randomized controlled trial. Int J Behav Nutr Phys Act. 2019;16(1):1-12.

48. Ban L, Guo S, Scherpbier RW, Wang X, Zhou H, Tata LJ. Child feeding and stunting prevalence in left-behind children: a descriptive analysis of data from a central and western Chinese population. Int $J$ Public Health. 2017;62(1):143-151.

49. Abebe Z, Haki GD, Baye K. Child feeding style is associated with food intake and linear growth in rural Ethiopia. Appetite. 2017;116:132-138.

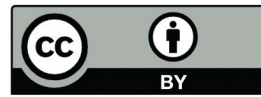

This work is licensed under a Creative Commons Attribution 